\title{
The Use of Candida pulcherrima in Combination with Saccharomyces cerevisiae for the Production of Chenin blanc Wine
}

\author{
N.P. Jolly ${ }^{1} *$, O.PH.Augustyn ${ }^{1}$ and I.S. Pretorius ${ }^{2 * *}$
}

(1) ARC Infruitec-Nietvoorbij, Private Bag X5026, 7599 Stellenbosch, South Africa

(2) Institute for Wine Biotechnology and Department of Viticulture \& Oenology, Stellenbosch University, Private Bag XI, 7602 Matieland (Stellenbosch), South Africa

Submitted for publication: February 2003

Accepted for publication: June 2003

Key words: Candida pulcherrima, Saccharomyces cerevisiae, yeasts, wine, fermentation

\begin{abstract}
Wine fermentations are conducted by naturally occurring or selected industrial wine yeast strains of Saccharomyces cerevisiae. However, non-Saccharomyces yeasts also occur naturally in fermenting grape musts, especially in the initial stages of the fermentation. It has been speculated that these yeasts can contribute to the overall characteristics of the wine. Generally, it is accepted that Kloeckera apiculata is the predominant nonSaccharomyces yeast species in grape must. However, it was shown previously that Candida pulcherrima was the predominant non-Saccharomyces yeast species in a grape must after sedimentation and prior to inoculation with commercial wine yeast. Subsequently, this yeast was investigated in laboratory and small-scale wine fermentations of Chenin blanc wine. As it could not ferment grape juice to dryness on its own, it was used in combination with a $S$. cerevisiae wine yeast strain. The effect of SO2, di-ammonium phosphate (DAP), pH and temperature on the growth of $C$. pulcherrima was also investigated. In combined fermentations, no change in overall fermentation rate or standard wine chemical analyses could be observed in comparison to a control $S$. cerevisiae fermentation. However, wine production in three consecutive years showed that the wine produced by the combined fermentation was of higher quality than that produced by the $S$. cerevisiae only.
\end{abstract}

In South Africa the most widely planted white grape variety is Chenin blanc. However, wines produced from this cultivar tend to be neutral in aroma and taste. A number of viticultural (pruning, ripeness at harvest) and winemaking practices (skin contact, postfermentation lees contact, maturation practices) are currently being investigated to improve wine quality. A further aspect receiving attention is the role of yeast.

Chenin blanc fermentations are normally conducted by selected Saccharomyces cerevisiae industrial wine yeast strains. However, non-Saccharomyces yeasts also occur naturally in fermenting grape musts, especially in the initial stages of the fermentation (Heard \& Fleet, 1985). It has been shown that some non-Saccharomyces yeasts can contribute to the overall characteristics of the wine (Romano et al, 1997; Soden et al., 2000). These facts were confirmed by Jolly et al. (2003a; 2003b). Furthermore, species present in higher numbers could be expected to have a greater effect on the fermentation and resultant wine quality than species present in lower numbers.

Generally, it is accepted that Kloeckera apiculata is the predominant non-Saccharomyces yeast species found in grape must (Fleet et al., 1984; Querol et al., 1990; Longo et al, 1991), but, as this yeast is usually associated with volatile acidity production, the potential for a positive contribution to wine quality is low (Romano et al., 1992; Gil et al, 1996). Previously, it was shown that Candida pulcherrima can also occur in high numbers in must (Schiitz \& Gafner, 1993; Jolly et al, 2003a). This nonSaccharomyces yeast is not normally associated with volatile acidity production, but can form relatively high concentrations of esters (Bisson \& Kunkee, 1991). These esters, as well as other metabolites could have a positive benefit for a Chenin blanc wine with neutral cultivar characteristics. While C. pulcherrima has been used to improve wine quality (Jolly et al., 2003b), it is not known how must $\mathrm{pH}$ and different winemaking practices, i.e. fermentation temperature, addition of di-ammonium phosphate (DAP) and SO2, will affect tiiis yeast. Therefore the aim of this study, which forms part of the ongoing research programme documented by Pretorius et al. (1999), was to investigate the effect of $\mathrm{pH}$, fermentation temperature, DAP and $\mathrm{SO}_{2}$ addition on the growth of C. pulcherrima. Subsequently, two C. pulcherrima isolates were investigated in small-scale wine fermentations over three vintages during the production of Chenin blanc wines.

\section{MATERIALS AND METHODS}

\section{Yeast strains}

Three yeast strains were used in this investigation, viz. C. pulcherrima (strains $825 \& \mathrm{Cl}-15$ ), previously isolated from vineyards and grape must from the Western Cape, South Africa (Jolly et al., 2003a) and an industrial S. cerevisiae yeast strain (strain

Corresponding author: E-mail address: neil@infruit.agric.za

**Present address: The Australian Wine Research Institute, P.O. Box 197, Glen Osmond, Adelaide, SA5064, Australia.

Acknowledgements: The authors thank Winetech forfinancial support, as well as the technical staff of the microbiology group of the Post-Harvest \& Wine Technology Division ofARC Infruitec-Nietvoorbij, F.J. Calitz of the Biometry Unit, H. Nieuwoudt of the Institute for Wine Biotechnology, Stellenbosch University and M. Blom of Distell, Stellenboschfor assistance. 
VIN 13, Anchor Bio-Technologies, South Africa). The first C. pulcherrima strain (strain 825) was selected randomly for wine production (Jolly et al., 2003b) and the second (strain Cl-15) was selected after screening 71 C. pulcherrima isolates from South African grape musts. The screening criteria were highest growth tempo, equal or lower formation of volatile acidity (in comparison to $S$. cerevisiae reference) and highest ethanol production in a grape must at $15^{\mathrm{C}} \mathrm{C}$. Strain 825 was used for the laboratory-scale fermentation and wine production for all three vintages, while strain $\mathrm{Cl}-15$ was used for wine production in the second and third vintages only.

\section{Laboratory-scale fermentations}

Four sets of laboratory-scale fermentations were conducted to determine the individual effects of $\mathrm{pH}$, temperature, DAP and $\mathrm{SO} 2$, respectively. A further two sets of fermentations were done to determine combined effects of the aforementioned (Table 1).

\section{Grape must}

$A$ previously frozen white grape must $\left(21.5^{\circ} \mathrm{B}\right.$ sugar, $5.6 \mathrm{~g} / \mathrm{L}$ total acidity, $\mathrm{pH} 3.4,0.50 \mathrm{~g} / \mathrm{L}$ volatile acidity and $1 \mathrm{mg} / \mathrm{L}$ total $\mathrm{SO}_{2}$ ) was used for all laboratory-scale fermentations. After thorough mixing, $500 \mathrm{~mL}$ aliquots were placed in $750 \mathrm{~mL}$ glass bottles and sterilised $\left(121^{\circ} \mathrm{C}\right.$ for $\left.15 \mathrm{~min}\right)$. The bottles were closed tightly by plastic fermentation caps filled with sterile distilled water. For the relevant experiments the $\mathrm{pH}$ was adjusted (3.2 \& 3.5), DAP

\section{TABLE 1}

The effect of four different winemaking practices on the slope of the logarithmic phase of the fermentation curve of laboratoryscale fermentations with Candida pulcherrima (strain 825) and S. cerevisiae (strain VIN 13).

\begin{tabular}{|c|c|c|c|}
\hline \multirow{2}{*}{\multicolumn{2}{|c|}{$\begin{array}{l}\text { Grape must parameter and } \\
\text { winemaking practice }\end{array}$}} & \multicolumn{2}{|c|}{ Slope $^{1}$} \\
\hline & & $\begin{array}{l}\text { C. pulcherrima } \\
\text { (strain 825) }\end{array}$ & $\begin{array}{c}\text { S. cerevisiae } \\
\text { (strain VIN 13) } \\
\text { (reference) }\end{array}$ \\
\hline \multicolumn{4}{|l|}{ Individual effects: } \\
\hline \multicolumn{2}{|l|}{ pH 3.2 (low) } & $1.08 \pm 0.14$ & $9.37 \pm 0.57$ \\
\hline \multicolumn{2}{|l|}{ pH 3.5 (high) } & $1.29 \pm 0.19$ & $\mathbf{9 . 0 4} \pm 0.45$ \\
\hline \multicolumn{2}{|l|}{ DAP (none) } & $1.04 \pm 0.09$ & $9.86 \pm 0.23$ \\
\hline \multicolumn{2}{|l|}{$\mathrm{DAP}(0,5 \mathrm{~g} / 1$ added $)$} & $1.35 \pm 0.07$ & $10.31 \pm 0.59$ \\
\hline Low temperature & $15^{\circ} \mathrm{C}$ & $1.06 \pm 0.66$ & $5.17 \pm 0.06$ \\
\hline Intermediate temperature & $20^{\circ} \mathrm{C}$ & $1.64 \pm 0.21$ & $14.92 \pm 0.23$ \\
\hline High temperature & $28^{\circ} \mathrm{C}$ & $1.82 \pm 0.21$ & $23.88 \pm 0.56$ \\
\hline \multicolumn{2}{|l|}{$\mathbf{S O}_{2}(0 \mathrm{mg} / 1)$} & $0.78 \pm 0.08$ & $8.38 \pm 0.35$ \\
\hline \multicolumn{2}{|l|}{$\mathrm{SO}_{2}(30 \mathrm{mg} / 1)$} & $0.80 \pm 0.10$ & $8.53 \pm 0.18$ \\
\hline \multicolumn{2}{|l|}{$\mathbf{S O}_{2}(60 \mathrm{mg} / 1)$} & $0.63 \pm 0.09$ & $8.40 \pm 0.12$ \\
\hline \multicolumn{4}{|c|}{ Combined effects: } \\
\hline \multirow{2}{*}{\multicolumn{2}{|c|}{$\begin{array}{l}28^{\circ} \mathrm{C} ; \mathrm{pH} 3.5 ; 0.5 \mathrm{~g} / \mathrm{L} \text { DAP; } \mathrm{No}^{\mathrm{SO}_{2}} \\
15^{\circ} \mathrm{C} ; \mathrm{pH} 3.2 ; \text { no DAP; } 60 \mathrm{mg} / \mathrm{L} \mathrm{SO} 2\end{array}$}} & $2.62 \pm 0.16$ & $22.62 \pm 0.55$ \\
\hline & & $0.54 \pm 0.13$ & $5.56 \pm 0.99$ \\
\hline
\end{tabular}

\footnotetext{
${ }^{1}$ Slope of the logarithmic phase of the fermentation curve $(\mathrm{m}=\mathrm{y} / \mathrm{x}-\mathrm{c} / \mathrm{x}$, where $\mathrm{m}$ is the slope of the logarithmic growth phase; $\mathrm{x}$ and $\mathrm{y}$ are the standard co-ordinates; and $\mathrm{c}$ is the $\mathrm{x}$-axis intercept). Average value of fermentations in triplicate \pm standard deviation.
}

$(0.5 \mathrm{~g} / \mathrm{L})$ and a $10 \%$ solution of sodium meta-bisulphite were added to give 30 and $60 \mathrm{mg} / \mathrm{L}$ total $\mathrm{SO}_{2}$. In the other instances no changes or additions were made to the must.

\section{Yeast inoculum andfermentation procedures}

Yeast starter cultures were grown for $24 \mathrm{~h}$ in YPD liquid medium ( $1 \%$ yeast extract, $2 \%$ peptone, $2 \%$ glucose). Total cell counts were carried out in a Neubauer improved bright-lined counting chamber (1 mm depth) and all inoculations were done at $1 \times 10^{6}$ cells/mL per yeast strain. The two $C$. pulcherrima strains were inoculated individually and all fermentations were conducted in triplicate. Reference fermentations were conducted by $S$. cerevisiae (strain VIN 13) only. The fermentation vessels were placed on an orbital shaker at $20^{\circ} \mathrm{C}$, except for the temperature experiment, where fermentations were conducted at 15,20 and $28^{\circ} \mathrm{C}$. Fermentations were monitored by $\mathrm{CO}_{2}$ weight loss and allowed to proceed until the reference fermentation was dry (14 days). Completion of fermentation (no further weight loss) was confirmed by use of glucose test strips (Clinistix, Bayer). The progression of $\mathrm{CO} 2$ weight loss was used to plot a fermentation curve. The slope of the logarithmic phase of the fermentation curve was calculated and used for comparison within an experiment as an indication of the yeast's ability to ferment.

\section{Small-scale wine production}

The $\boldsymbol{C}$. pulcherrima yeast strains were investigated in combination with the 5. cerevisiae for small-scale production of Chenin blanc wine.

\section{Grape must}

The Chenin blanc grapes were commercially harvested from the vineyards of the ARC Infruitec-Nietvoorbij Research Institute, Stellenbosch. After crushing and sedimentation $(0.5 \mathrm{~g} / \mathrm{hL}$ Ultrazym, Novazymes, Denmark), the clear juice was racked off the lees and divided into the fermentation containers. The chemical analyses for the musts were: $21.7^{\circ} \mathrm{B}$ sugar, $6.9 \mathrm{~g} / \mathrm{L}$ total acidity, $\mathrm{pH} 3.71 ; 23.0^{\circ} \mathrm{B}$ sugar, $7.8 \mathrm{~g} / \mathrm{L}$ total acidity, $\mathrm{pH} 3.33$; and $24.3^{\circ} \mathrm{B}$ sugar, $6.8 \mathrm{~g} / \mathrm{L}$ total acidity and $\mathrm{pH} 3.55$ for the $2000,200 \mathrm{~J}$ and 2002 vintages, respectively. Di-ammonium phosphate $(0.5$ $\mathrm{g} / \mathrm{L})$ and $10 \%$ sodium meta-bisulphite solution $(50 \mathrm{mg} / \mathrm{L}$ total $\mathrm{SO} 2)$ were added before fermentation.

\section{Fermentation procedure}

The $C$. pulcherrima yeasts were propagated in the same way as for the laboratory-scale fermentations and inoculated at a concentration of $1 \times 10^{6}$ cells $/ \mathrm{mL}$ into $18 \mathrm{~L}$ of the freshly prepared grape musts. This first inoculation was followed one hour later by an active dried $S$. cerevisiae (strain VIN 13) inoculation at a concentration of $0.04 \mathrm{~g} / \mathrm{L}$. A reference grape must was inoculated with the $S$. cerevisiae only. Wine production was done in duplicate and continued as described by Jolly et al. (2003b).

\section{Sensory evaluation of small-scale wines}

The wines (small-scale only) were subjected to a sensory evaluation by different panels of seven trained wine tasters. Descriptive sensory analyses were done on all the wines five months after production. A ten-centimetre unstructured line scale was used and the judges were asked to rate 'fruity' and 'guava' aroma intensity (undetectable to prominent) and general quality (unacceptable to excellent). In addition, wines from the first two vintages were evaluated at five and 18 months, while wines from the third vin- 
tage were evaluated at five months only according to the multiwine preferences method (McCloskey et al., 1995). Further wine evaluation protocols were according to Jolly et al. (2003b).

\section{Chemical and statistical analyses}

The wines (laboratory and small-scale) were analysed for alcohol (infralyser technique - Cape Wine Laboratory, Stellenbosch), glycerol (enzymatic test kits, Boehringer Mannheim, Roche, Germany; and Winescan, Institute for Wine Biotechnology, Stellenbosch University), and for residual sugar (Rebelein), volatile acidity and $\mathrm{SO}_{2}$ as described by Hand et al. (2000). Analyses for esters (volatile component analyses - Research Chemistry, Distell, Stellenbosch) were carried out at the time of the five-month sensory evaluations on the small-scale wines only. Analysis of variance was performed on the ester values and the descriptive sensory analyses values using SAS version 8.2 (SAS, 1999). The Shapiro-Wilk test was done to test for non-normality (Shapiro \& Wilk, 1965) and Student's t-Least Significant Difference was calculated at the 5\% confidence level to compare treatment means (Ott, 1998).

\section{RESULTS AND DISCUSSION}

As our $C$. pulcherrima isolates could not ferment a grape must to dryness on their own (Fig. 1), they needed to be co-inoculated with a $S$. cerevisiae wine yeast. The $S$. cerevisiae strain chosen for this, viz. VIN 13, is recommended by the manufacturers for the production of aromatic white wines at low temperatures. This made it an ideal choice for Chenin blanc production. It is also a strong fermentor and is not generally implicated in stuck fermentations. Although it has previously been reported that some strains of $C$. pulcherrima have an inhibitory effect against $S$. cerevisiae (Nguyen \& Panon, 1998), the two strains used in this investigation did not show this effect against $S$. cerevisiae strain VIN 13 (data not shown). It was, however, expected that the $S$. cerevisiae would be competing for the same nutrients as the $C$. pulcherrima, but there was no reduction in fermentation rate in comparison to the VIN 13 reference fermentation (Fig. 1). Typically, C. pulcherrima could be detected until the ninth day of a co-inoculated 14-day fermentation by streaking 200(iL aliquots onto lysine medium and checking for colonies producing the red-brown pigment pulcherrimin (Heard \& Fleet, 1986; Miller \& Phaff, 1998; Jolly et al., 2003b). The one-hour time lapse between inoculating the $C$. pulcherrima and the $S$. cerevisiae yeast was chosen to allow the $C$. pulcherrima to adapt to the must and start its growth, before being dominated by the $S$. cerevisiae. In addition, the short time lapse before the start of fermentation will minimise any detrimental oxidation of the must. Placement of the fermentation vessels on the orbital shaker copied the natural turbulence found in large fermentations due to the generation of $\mathrm{CO}_{2}$ (Henschke, 1990). The tightly sealed fermentation caps ensured that no oxygen entered the fermentation vessel.

\section{Laboratory-scale fermentations}

The manipulation of winemaking practices (use of DAP and SO2), fermentation temperature and must $\mathrm{pH}$ generally had similar effects on the fermentation ability of $C$. pulcherrima and the $S$. cerevisiae reference strain (Table 1). Di-ammonium phosphate addition, higher $\mathrm{pH}$ values and increased temperatures all resulted in a slight increase in the fermentation ability of strain 825 as is shown by the increased slope of the logarithmic phase of the fermentation curve. However, the increase in fermentation ability due to increased fermentation temperature was not as dramatic as for the $S$. cerevisiae reference. Higher levels of ethanol were also formed (Table 2), reflecting a more efficient fermentation by strain 825 .

Sulphur dioxide in the concentration range normally used in wine fermentation, i.e. 0-30 mg/L, did not affect the fermentation ability

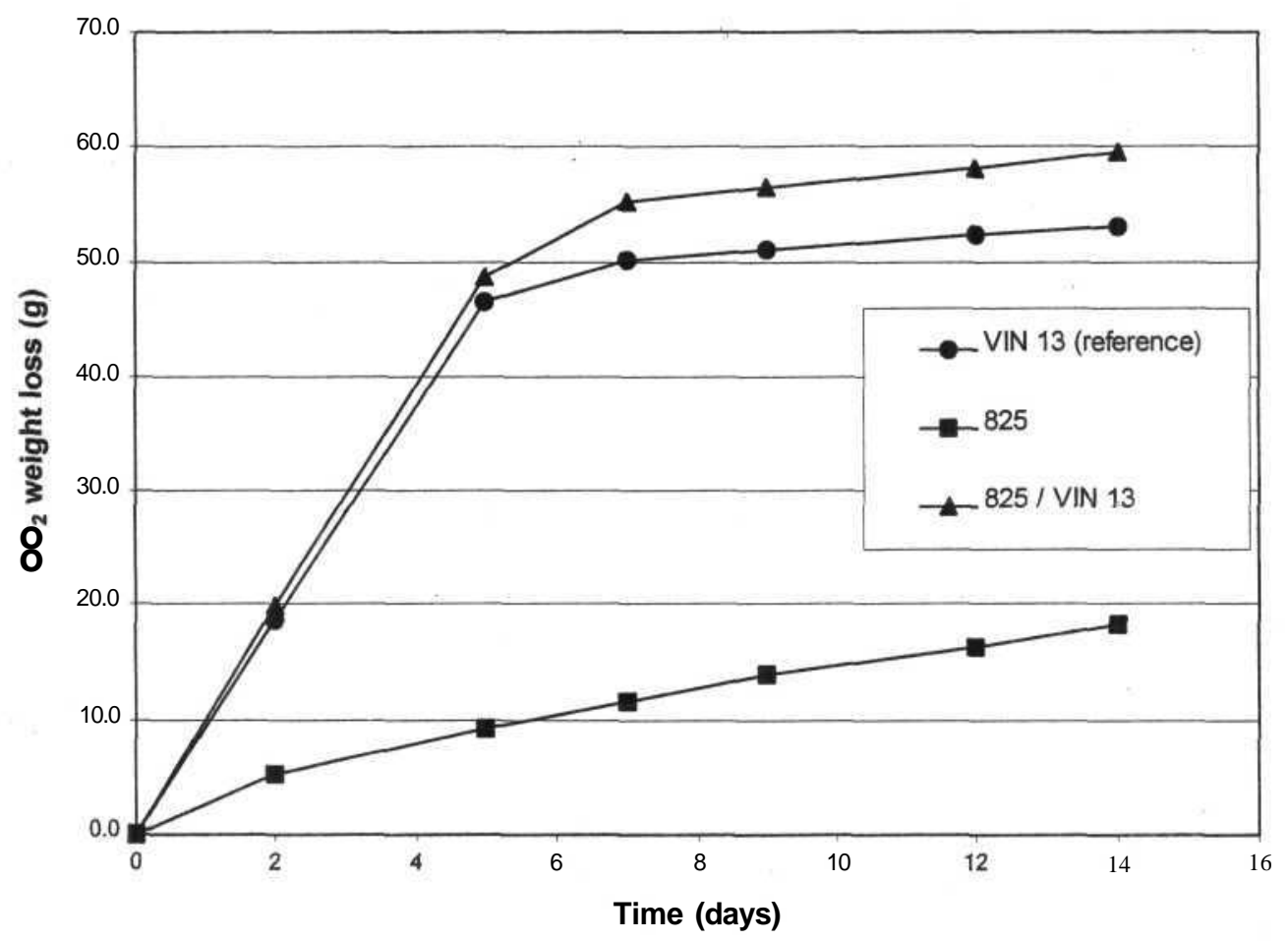

FIGURE 1

Laboratory-scale fermentation curves of C. pulcherrima (strain 825) and S. cerevisiae (strain VTN 13) compared to a combined $S$. cerevisiae/C. pulcherrima fermentation. 
TABLE 2

The effect of four different winemaking practices on chemical analyses of wines produced by laboratory-scale fermentations with Candida pulcherrima (strain 825).

Chemical analyses ${ }^{1}$

\begin{tabular}{|c|c|c|c|c|c|c|c|}
\hline \multicolumn{2}{|c|}{$\begin{array}{l}\text { Alcohol } \\
(\% \mathrm{v} / \mathrm{v})\end{array}$} & \multicolumn{2}{|c|}{$\begin{array}{l}\text { Volatile acidity } \\
\qquad(\mathrm{g} / \mathrm{L})\end{array}$} & \multicolumn{2}{|c|}{$\underset{(\mathrm{mg} / \mathrm{L})}{\mathbf{T}}$} & \multicolumn{2}{|c|}{$\begin{array}{c}\text { Glycerol } \\
\text { (g/L) }\end{array}$} \\
\hline 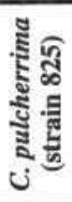 & 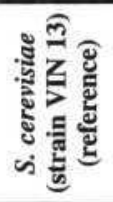 & 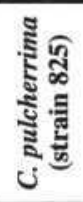 & 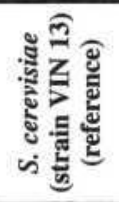 & 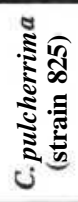 & 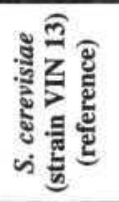 & 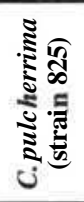 & 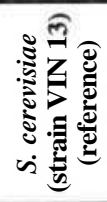 \\
\hline
\end{tabular}

\section{Individual effects:}

\begin{abstract}
pH 3.2 (low)
\end{abstract}
pH 3.5 (high)

DAP (none)

DAP $(0,5 \mathrm{~g} / 1$ added $)$

Low temperature:

Intermediate temperature:

High temperature:

$\mathrm{SO}_{2} \quad(0 \mathrm{mg} / \mathrm{l})$

$\mathrm{SO}_{2}(30 \mathrm{mg} / 1)$

$\mathrm{SO}_{2}(60 \mathrm{mg} / 1)$

Combined effects:

$28^{\circ} \mathrm{C} ; \mathrm{pH} 3.83 ; 0.5 \mathrm{~g} / \mathrm{L}$ DAP; $\mathrm{No}_{2}$

$15^{\circ} \mathrm{C}$; pH 3.2; no DAP; $60 \mathrm{mg} / \mathrm{L} \mathrm{SO}_{2}$

$\begin{array}{ll}3.2 \pm 0.1 & 12.8 \pm 0.1 \\ 3.6 \pm 0.1 & 12.9 \pm 0.1 \\ 3.2 \pm 0.2 & 12.8 \pm 0.1 \\ 3.5 \pm 0.2 & 12.8 \pm 0.1 \\ 3.9 \pm 0.5 & 12.5 \pm 0.1 \\ 4.4 \pm 0.2 & 12.5 \pm 0.1 \\ 3.7 \pm 0.2 & 12.5 \pm 0.1 \\ 2.7 \pm 0.2 & 12.8 \pm 0 \\ 2.5 \pm 0.1 & 12.8 \pm 0 \\ 2.2 \pm 0.1 & 12.8 \pm 0.1\end{array}$

$\begin{array}{ll}0.22 \pm 0.02 & 0.20 \pm 0.01 \\ 0.24 \pm 0.01 & 0.18 \pm 0.02 \\ 0.23 \pm 0.01 & 0.23 \pm 0.03 \\ 0.25 \pm 0.02 & 0.19 \pm 0.04 \\ 0.14 \pm 0.04 & 0.18 \pm 0.04 \\ 0.14 \pm 0.02 & 0.14 \pm 0.02 \\ 0.14 \pm 0.01 & 0.32 \pm 0.01 \\ 0.25 \pm 0.01 & 0.35 \pm 0.01 \\ 0.23 \pm 0.01 & 0.33 \pm 0.02 \\ 0.19 \pm 0.03 & 0.35 \pm 0.02\end{array}$

$1.2 \pm 0.1 \quad 13.5 \pm 0.1$

$0.7 \pm 0.5 \quad 13.7 \pm 0.4$

$0.15 \pm 0 \quad 0.21 \pm 0.0$

$\begin{array}{cc}14 \pm 1 & 21 \pm 2 \\ 14 \pm 1 & 20 \pm 1 \\ 18 \pm 2 & 27 \pm 1 \\ 18 \pm 1 & 30 \pm 1 \\ 12 \pm 1 & 24 \pm 1 \\ 12 \pm 2 & 17 \pm 1 \\ 15 \pm 1 & 17 \pm 1 \\ 17 \pm 2 & 22 \pm 1 \\ 25 \pm 2 & 37 \pm 3 \\ 61 \pm 1 & 59 \pm 4 \\ & \\ 7 \pm 2 & 11 \pm 1 \\ 38 \pm 2 & 46 \pm 1\end{array}$

$5.17 \pm 0.96 \quad 6.15 \pm 0.16$

$5.51 \pm 0.67 \quad 6.60 \pm 0.10$

$6.14 \pm 0.52 \quad 6.48 \pm 0.48$

$6.38 \pm 0.14 \quad 6.16 \pm 0.43$

$6.88 \pm 0.96 \quad 5.76 \pm 0.35$

$6.75 \pm 1.22 \quad 5.92 \pm 0.11$

$5.36 \pm 1.51 \quad 6.21 \pm 0.10$

$7.14 \pm 0.07 \quad 5.05 \pm 0.37$

$6.06 \pm 0.38 \quad 5.78 \pm 0.57$

$4.81 \pm 0.63 \quad 5.40 \pm 0.12$

$11 \pm 1$

$12.17 \pm 0.57 \quad 7.20 \pm 0.10$

$38 \pm 2$

$6.87 \pm 1.31 \quad 7.43 \pm 0.06$ of 825. This contrasts with the accepted opinion that all nonSaccharomyces yeasts are sensitive to wine-related $\mathrm{SO}_{2}$ levels. Under normal winemaking conditions, the growth of $C$. pulcherri$m a$ strain 825 therefore will not be hampered by $\mathrm{SO}_{2}$. This insensitivity to $\mathrm{SO}_{2}$ was also noted by Granchi et al. (1998), who found that $\mathrm{SO}_{2}$ in the range of $50-100 \mathrm{mg} / \mathrm{L}$ did not succeed in preventing the growth of non-Saccharomyces yeasts in Sangiovese wine fermentations. However, at higher $\mathrm{SO}_{2}$ concentrations, i.e. $60 \mathrm{mg} / \mathrm{L}$, the growth of 825 was slightly retarded, as also reflected in the lower alcohol, volatile acidity and glycerol levels. In comparison, the VEST 13 fermentation ability remained unaffected. Excessive volatile acidity, which is often formed when yeasts grow under stress conditions (lower temperature, $\mathrm{pH}$ and nitrogen limitation), was not formed by strain 825 during the laboratory-scale fermentations.

The combined effects of lower temperature, low $\mathrm{pH}$, no DAP and high $\mathrm{SO}_{2}$ had a limiting effect while, as expected, the combined conditions of higher temperature, higher $\mathrm{pH}$ with the addition of DAP and no $\mathrm{SO}_{2}$ enhanced $C$. pulcherrima growth (Table 1). Furthermore, the chemical analyses (Table 2) show a marked increase in the glycerol concentration. This is supported by a reduction in alcohol of $2 \%$ when compared to the previous fermentations (individual effects). This phenomenon was not observed in the previous investigations (Jolly et al., 2003b) and may be due to the high $\mathrm{pH}$ and fermentation temperature.

In a warm climate like that of South Africa, where must $\mathrm{pH}$ tends to be high and red wine fermentation temperatures can exceed $25^{\circ} \mathrm{C}$, these yeasts, which are present naturally (Jolly et al., 2003a), may already be playing a role in wine quality. Their role would be smaller at lower fermentation temperatures in low $\mathrm{pH}$ musts.

\section{Screening of $\boldsymbol{C}$. pulcherrima isolates for wine production $\cdot{ }_{t}$}

As $C$. pulcherrima strain 825 has a low fermentation ability, a stronger fermentor was desired so that the yeast could make a greater impact on the fermentation. Therefore, fermentation ability and alcohol production were chosen as selection criteria. Production of volatile acidity, as potentially detrimental to wine quality, was also checked. A fermentation temperature of $15^{\circ} \mathrm{C}$ was used, as it is most representative of the production of South African Chenin blanc in a fruity, non-wooded style.

The screening results (data not shown) did not show much variation from strain 825, although strain $\mathrm{Cl}-15$ showed an improvement in fermentation ability, which was also reflected in a marginal improvement in alcohol production (Table 3 ). The volatile acidity was lower than that of strain 825 and comparable to that of the $S$. cerevisiae reference.

\section{Small-scale wine production}

\section{Chemical analyses}

The fermentations for all three vintages were completed and there were no marked differences between the standard wine chemical analyses of the $S$. cerevisiae reference wine and the wines produced by the $C$. pulcherrimalS. cerevisiae combinations (Table 4 ). No yeast counts were done during the fermentations; howev- 
er, it was previously shown that $C$. pulcherrima could be detected for approximately two thirds of a combined fermentation (Jolly et al., 2003b) and the same scenario was expected to have occurred here. The combined fermentations did show a tendency towards lower residual sugars than the $S$. cerevisiae monoculture. This shows a more efficient must sugar utilisation by the dual culture and was also noted by Ciani \& Ferraro (1998) in their combined fermentations with $C$. stellata and $S$. cerevisiae. No increased glycerol concentration, as was the case in the laboratory-scale fermentation, was noted. However, this may have been due to the fermentation taking place at $15^{\circ} \mathrm{C}$ and not at $28^{\circ} \mathrm{C}$.

It has been reported previously that $C$. pulcherrima yeasts are high ester producers (Bisson \& Kunkee, 1991). As mentioned in the introduction, esters can make a positive contribution to a Chenin blanc wine with neutral cultivar characteristics, even though this may be of short duration. Gas chromatographic analyses of total esters, total higher alcohols and total acids showed no significant differences between the $S$. cerevisiae reference wines and the $C$. pulcherrima/S. cerevisiae combinations (Table 5). This may be due to there not being enough $C$. pulcherrima yeast or that a longer period is needed for ester formation to become apparent. The results of the 2001 and 2002 vintages therefore confirmed the findings of Jolly et al. (2003b) that C. pulcherrima strains 825 and Cl-5 did not make a contribution to total esters in the wine under the conditions used.

\section{Sensory evaluation}

Sensory evaluation can be subjective. However, the human nose is capable of detecting aroma, flavour and other sensory nuances that are not measurable by current instrumentation. Furthermore, in the wine industry most decisions regarding wine quality with the subsequent economic implications often rely more on sensory evaluation and less on chemical analyses. Sensory evaluation is also the final criterion for judging any wine-making manipulation.

In this investigation the sensory evaluation of the two wine types by descriptive analyses (Table 6) showed that, for the 2000 vintage wines, there was no significant difference in aroma profile and quality of the five-month old wines. However, the C. pulcherrima (strain 825) wine did have a higher aroma note of 'guava'. Wines from the second vintage (2001) were judged to differ more from each other, with the C. pulcherrima wines having the highest scores for 'guava'. For the wines produced with strain $\mathrm{Cl}-15$, this was significantly higher than the reference wine (S. cerevisiae only). The 'fruity' aroma note and 'general quality' were judged to be similar (no significant difference). Wines from the third vintage (2002) were again judged similar for 'fruity', but the $C$. pulcherrima strain $\mathrm{Cl}-15$ wine again scored the highest for

\section{TABLE 3}

Comparison of two C. pulcherrima strains and one S. cerevisiae strain for three selection criteria during fermentations at $15^{\circ} \mathrm{C}$.

\begin{tabular}{|c|c|c|c|}
\hline \multirow[t]{2}{*}{ Yeast strain } & \multicolumn{3}{|c|}{ Selection criteria $^{1}$} \\
\hline & Slope $^{2}$ & $\begin{array}{l}\text { Alcohol } \\
\left(\begin{array}{ll}\% & \mathrm{v} / \mathrm{v})\end{array}\right.\end{array}$ & $\begin{array}{c}\text { Volatile acidity } \\
\text { (g/L) }\end{array}$ \\
\hline S. cerevisiae (reference 1 ) & $5.26(5.13-5.39)$ & $12.6(12.5-12.6)$ & $0.33(0.33-0.33)$ \\
\hline C. pulcherrima (strain 825) (reference 2) & $0.67(0.65-0.68)$ & $3.3(3.1-3.4)$ & $0.39(0.37-0.40)$ \\
\hline C. pulcherrima (strain $\mathrm{Cl}-15)$ & $1.16(0.77-1.55)$ & $4.6(3.4-5.7)$ & $0.35(0.30-0.40)$ \\
\hline
\end{tabular}

${ }^{1}$ Average of duplicate fermentation at $15^{\circ} \mathrm{C}$. Range indicated in brackets.

${ }^{2}$ Slope of the logarithmic growth phase of the fermentation curve $(\mathrm{m}=\mathrm{y} / \mathrm{x}-\mathrm{c} / \mathrm{x}$, where $\mathrm{m}$ is the slope of the logarithmic growth phase; $\mathrm{y}$ is the $\mathrm{y}$ co-ordinate; $\mathrm{x}$ is the $\mathrm{x}$ co-ordinate; and $\mathrm{c}$ is the $\mathrm{x}$-axis intercept).

\section{TABLE 4}

Chemical analyses of Chenin blanc wines fermented by $C$. pulcherrima/S. cerevisiae combinations during small-scale wine production at $15^{\circ} \mathrm{C}$.

\begin{tabular}{|c|c|c|c|c|c|c|}
\hline \multirow[t]{2}{*}{ Yeast strain combination } & \multirow[t]{2}{*}{ Vintage } & \multicolumn{5}{|c|}{ Chemical analyses ${ }^{1}$} \\
\hline & & $\begin{array}{c}\text { Residual sugar } \\
(\mathrm{g} / \mathbf{1})\end{array}$ & $\begin{array}{l}\text { Ethanol } \\
(\% \quad \mathrm{v} / \mathrm{v})\end{array}$ & $\begin{array}{c}\text { Volatile acidity } \\
\qquad(8 / 1)\end{array}$ & $\underset{(\mathrm{mg} / \mathbf{1})}{\mathrm{Total} \mathrm{SO}_{2}}$ & $\begin{array}{l}\text { Glycerol } \\
\text { (g/1) }\end{array}$ \\
\hline S. cerevisiae (reference) & $2000^{2}$ & $1.2(1.0-1.4)$ & 13.2(13.1-13.2) & $0.19(0.18-0.19)$ & $104(104-104)$ & $5.6(5.5-5.6)$ \\
\hline C. pulcherrima (strain 825)/S. cerevisiae & $2000^{2}$ & $0.9(0.2-1.6)$ & $13.0(12.9-13.0)$ & $0.19(0.18-0.19)$ & $98(94-101)$ & $5.6(5.5-5.6)$ \\
\hline S. cerevisiae (reference) & 2001 & $1.8(1.6-2.0)$ & $14.6(14.6-14.6)$ & $0.29(0.28-0.29)$ & $95(90-100)$ & $7.7(7.5-7.8)$ \\
\hline C. pulcherrima (strain 825)/S. cerevisiae & 2001 & $1.4(1.2-1.5)$ & $14.6(14.5-14.6)$ & $0.28(0.27-0.28)$ & $82(81-82)$ & $7.9(7.8-7.9)$ \\
\hline C. pulcherrima (strain Cl-15) / S. cerevisiae & 2001 & $1.2(1.2-1.2)$ & $14.6(14.6-14.6)$ & $0.29(0.28-0.30)$ & $88(82-93)$ & $7.8(7.8-7.8)$ \\
\hline S. cerevisiae (reference) & 2002 & $1.95(1.90-2.00)$ & $14.9(14.7-15.1)$ & $0.25(0.24-0.26)$ & $115(115-115)$ & $7.9(7.7-8.0)$ \\
\hline C. pulcherrima (strain 825 ) / S. cerevisiae & 2002 & $1.90(1.90-1.90)$ & $15.0(14.9-15.0)$ & $0.26(0.25-0.27)$ & 113(111-115) & $7.7(7.7-7.7)$ \\
\hline C. pulcherrima (strain Cl-15)/S. cerevisiae & 2002 & $1.90(1.90-1.90)$ & $15.0(15.0-15.0)$ & $0.26(0.25-0.27)$ & $117(115-118)$ & $8.0(8.0-8.0)$ \\
\hline
\end{tabular}

${ }^{1}$ Average values of duplicate fermentations. Range indicated in brackets.

${ }^{2}$ Data for the 2000 vintage obtained from Jolly et al. (2003b). 


\section{TABLE 5}

Gas chromatographic analysis of Chenin blanc wines of the 2000, 2001 and 2002 vintages fermented by C. pulcherrima/S. cerevisiae combinations during small-scale wine production.

\begin{tabular}{|c|c|c|c|c|c|c|c|c|}
\hline Yeast Combination & Vintage $^{1}$ & $\begin{array}{c}\begin{array}{c}\text { Total } \\
\text { esters }^{2}\end{array} \\
(\mathrm{mg} / \mathrm{L})\end{array}$ & $\begin{array}{c}\text { Total higher } \\
\text { alcohols }^{2} \\
(\mathrm{mg} / \mathrm{L})\end{array}$ & $\begin{array}{c}\text { Total } \\
\text { acids }^{2} \\
(\mathrm{mg} / \mathrm{L})\end{array}$ & $\begin{array}{c}\text { Ethyl- } \\
\text { acetate }^{2} \\
(\mathrm{mg} / \mathrm{L})\end{array}$ & $\begin{array}{c}\text { Total esters } \\
\text {-ethyl acetate }^{2} \\
(\mathrm{mg} / \mathrm{L})\end{array}$ & $\begin{array}{c}\text { Ethyl- } \\
\text { lactate }^{2} \\
(\mathrm{mg} / \mathrm{L})\end{array}$ & $\begin{array}{c}\text { Total esters } \\
\text {-ethyl acetate } \\
\text {-ethyl lactate } \\
(\mathrm{mg} / \mathrm{L})\end{array}$ \\
\hline S. cerevisiae (reference) & 2000 & $216.06 \mathrm{a}$ & $321.45 \mathrm{a}$ & $233.64 a$ & $176.35 \mathrm{a}$ & $39.71 \mathrm{a}$ & $11.41 \mathrm{a}$ & $28.30 \mathrm{a}$ \\
\hline $\begin{array}{l}\text { C. pulcherrima (strain } 825) / \\
\text { S. cerevisiae }\end{array}$ & 2000 & $231.62 \mathrm{a}$ & $311.33 \mathrm{a}$ & $195.60 \mathrm{a}$ & $188.32 \mathrm{a}$ & $43.31 \mathrm{a}$ & $13.97 \mathrm{a}$ & $29.34 \mathrm{a}$ \\
\hline S. cerevisiae (reference) & 2001 & $109.04 \mathrm{a}$ & $194.40 \mathrm{a}$ & $21.54 \mathrm{a}$ & $57.13 \mathrm{a}$ & $51.91 \mathrm{a}$ & $15.96 \mathrm{a}$ & $35.95 \mathrm{a}$ \\
\hline $\begin{array}{l}\text { C. pulcherrima (strain } 825) / \\
\text { S. cerevisiae }\end{array}$ & 2001 & $109.19 a$ & $198.84 a$ & $20.90 b$ & $56.25 \mathrm{a}$ & $52.94 \mathrm{a}$ & $16.78 \mathrm{a}$ & $36.17 \mathrm{a}$ \\
\hline $\begin{array}{l}\text { C. pulcherrima (strain Cl-15) / } \\
\text { S. cerevisiae }\end{array}$ & 2001 & $110.50 \mathrm{a}$ & $195.84 \mathrm{a}$ & $21.65 \mathrm{a}$ & $56.76 \mathrm{a}$ & $53.74 \mathrm{a}$ & $15.21 \mathrm{a}$ & $38.53 a$ \\
\hline S. cerevisiae (reference) & 2002 & $127.18 \mathrm{a}$ & $208.52 \mathrm{a}$ & $32.63 \mathrm{a}$ & $98.68 \mathrm{a}$ & $28.51 \mathrm{a}$ & $5.21 \mathrm{a}$ & $23.3 \mathrm{a}$ \\
\hline $\begin{array}{l}\text { C. pulcherrima (strain } 825) / \\
\text { S. cerevisiae }\end{array}$ & 2002 & $122.40 \mathrm{a}$ & $202.90 \mathrm{a}$ & $30.75 a$ & $94.92 \mathrm{a}$ & $27.48 \mathrm{a}$ & $4.87 \mathrm{a}$ & $22.62 \mathrm{a}$ \\
\hline $\begin{array}{l}\text { C. pulcherrima (strain C1-15)/ } \\
\text { S. cerevisiae }\end{array}$ & 2002 & $117.30 \mathrm{a}$ & $203.70 \mathrm{a}$ & $29.95 \mathrm{a}$ & $90.97 \mathrm{a}$ & $26.34 \mathrm{a}$ & 4.71a & $21.62 \mathrm{a}$ \\
\hline
\end{tabular}

${ }^{1}$ Data for the 2000 vintage obtained from Jolly et al. (2003b).

${ }^{2}$ Average value of two wines. Values within columns, for the same vintage, followed by the same letter do not differ significantly ( $\mathrm{p}<0.05$ ).

\section{TABLE 6}

Descriptive sensory analyses of five-month-old Chenin blanc wines produced by combinations of C. pulcherrima and 5. cerevisiae yeasts for the 2000, 2001 and 2002 vintages.

\begin{tabular}{|c|c|c|c|c|c|c|c|c|c|}
\hline \multirow[t]{3}{*}{ Yeast strain } & \multicolumn{9}{|c|}{ Wine characteristic $(\%)^{\prime}$} \\
\hline & \multicolumn{3}{|c|}{2000 vintage } & \multicolumn{3}{|c|}{2001 vintage } & \multicolumn{3}{|c|}{2002 vintage } \\
\hline & $\begin{array}{c}\text { Fruity } \\
\text { aroma } \\
\text { intensity }\end{array}$ & $\begin{array}{c}\text { Guava } \\
\text { aroma } \\
\text { intensity }\end{array}$ & $\begin{array}{l}\text { General } \\
\text { quality }\end{array}$ & $\begin{array}{c}\text { Fruity } \\
\text { aroma } \\
\text { intensity }\end{array}$ & $\begin{array}{c}\text { Guava } \\
\text { aroma } \\
\text { intensity }\end{array}$ & $\begin{array}{l}\text { General } \\
\text { quality }\end{array}$ & $\begin{array}{c}\text { Fruity } \\
\text { aroma } \\
\text { intensity }\end{array}$ & $\begin{array}{c}\text { Guava } \\
\text { aroma } \\
\text { intensity }\end{array}$ & $\begin{array}{l}\text { General } \\
\text { quality }\end{array}$ \\
\hline S. cerevisiae (reference) & $44.79 \mathrm{a}$ & $16.57 \mathrm{a}$ & $48.86 \mathrm{a}$ & $52.92 \mathrm{a}$ & $25.17 \mathrm{~b}$ & $52.50 \mathrm{a}$ & $64.00 \mathrm{ab}$ & $25.14 \mathrm{a}$ & $49.43 b$ \\
\hline $\begin{array}{l}\text { C. pulcherrima (strain } 825) / \\
\text { 5. cerevisiae }\end{array}$ & $43.57 \mathrm{a}$ & $21 \mathrm{a}$ & $52.36 \mathrm{a}$ & $59.50 \mathrm{a}$ & $28.83 \mathrm{ab}$ & $50.33 \mathrm{a}$ & $57.86 b$ & $23.57 \mathrm{a}$ & $53.43 \mathrm{ab}$ \\
\hline $\begin{array}{l}\text { C. pulcherrima (strain } \mathrm{Cl}-15) / \\
\text { S. cerevisiae }\end{array}$ & -2 & -2 & -2 & $49.25 \mathrm{a}$ & $42.83 \mathrm{a}$ & $48.00 \mathrm{a}$ & $67.86 \mathrm{a}$ & $30.00 \mathrm{a}$ & $60.57 \mathrm{a}$ \\
\hline
\end{tabular}

${ }^{1}$ Average value of duplicate wines judged by panels of seven judges. Values within columns for the same vintage, followed by the same letter, do not differ significantly $(\mathrm{p}<0.05)$.

${ }^{2}$ Not produced during the 2000 vintage.

the 'guava' aroma note (although not statistically significant). The quality of the $\mathrm{Cl}-15$ wine was also significantly better than the reference wine.

The wines were also tasted according to the multi-wine preference method (McCloskey et al., 1995) to obtain a relative score. During this evaluation the judges were asked to judge overall wine quality (inclusive of wine colour, aroma, flavour and body/mouthfeel). From Table 7 can be seen that the combined C. pulcherrima/S. cerevisiae wines always scored higher than the reference wine produced by the $S$. cerevisiae only over the three vintages investigated. This, despite the possible subjectivity of the measuring instrument, should be considered significant.
Furthermore, in the two vintages for which the selected $C$. pulcherrima strain $\mathrm{Cl}-15$ was used, that wine received the highest rating. This supports the choice of selection criteria used for selecting C1-15. It was further noted in the 2002 vintage that the wines judged to be better had lower total ester values than the reference wine (Tables $5 \& 7$ ), indicating that other metabolites were playing a role in wine quality.

From the data presented it appears that the effect of the C. pulcherrima strains in wine fermentation was more complex than could be measured by the chemical techniques used. At this stage of the investigation it is also not yet clear by how much wine quality can be improved. Strain selection criteria could also be 
TABLE 7

Relative score of Chenin blanc wines fermented by $C$. pulcherrima I S. cerevisiae combinations during small-scale wine production.

\begin{tabular}{|c|c|c|c|c|c|}
\hline \multirow{3}{*}{ Yeast combination } & \multicolumn{5}{|c|}{ Vintage / Time of evaluation / Relative score ${ }^{1}$} \\
\hline & \multicolumn{2}{|c|}{2000 vintage $^{2}$} & \multicolumn{2}{|c|}{2001 vintage } & 2002 vintage \\
\hline & 5 months & 18 months & 5 months & 18 months & 5 months \\
\hline S. cerevisiae (reference) & $-2(-5,1)$ & $-1(-5,3)$ & $-2(-3,-1)$ & $-2(-3,-1)$ & $-1(-3,1)$ \\
\hline $\begin{array}{l}\text { C. pulcherrima (strain } 825) / \\
\text { S. cerevisiae }\end{array}$ & $2(1,3)$ & $5(5,5)$ & $1(-1,3)$ & $-1(-5,3)$ & $0(-1,1)$ \\
\hline $\begin{array}{l}\text { C. pulcherrima (strain Cl-15) / } \\
\text { 5. cerevisiae }\end{array}$ & -3 & -3 & $4(1,7)$ & $3(1,5)$ & $1(1,1)$ \\
\hline
\end{tabular}

${ }^{1}$ Average score of two wines evaluated by the multi-wine preference method (McCloskey et ah, 1995). Only values within a column are related to each other.

Highest score in bold type. Range indicated in brackets.

${ }^{2}$ Data for the 2000 vintage obtained from Jolly et al., $2003 \mathrm{~b}$.

${ }^{3}$ Not produced during the 2000 vintage.

sharpened, while combinations with other strains of 5 . cerevisiae can also be investigated, bearing in mind the possible inhibitory effect that $C$. pulcherrima may have on some 5. cerevisiae strains. Scaling up to pilot and commercial scale should also be carried out, while the extent to which the $C$. pulcherrima yeasts survive during the fermentation can also be ascertained, enabling winemaking conditions to be adjusted so that the survival and growth of the $C$. pulcherrima yeast is optimised.

\section{CONCLUSIONS}

The effects of $\mathrm{pH}, \mathrm{SO} 2, \mathrm{DAP}$ addition and temperature on $C$. pulcherrima follows the same pattern as that on $S$. cerevisiae. However, elevated levels of $\mathrm{SO}_{2}$ can suppress the growth of $C$. pulcherrima, but these levels are much higher than normally found in practice. The use of a selected strain of C. pulcherrima had a positive influence on wine quality not linked to ester levels, which also did not detrimentally affect standard wine chemical analyses. Further isolation from grape musts and strain selection for more vigorous strains will make it possible to optimise the improved quality contribution. Further chemical analyses and methodology development could identify the metabolites responsible for this quality improvement. In the interim, the selected strains could be employed for the improvement of South African Chenin blanc wines.

\section{LITERATURE CITED}

Bisson, L.F. \& Kunkee, R.E., 1991. Microbial interactions during wine production. In: Zeikus, J.G. \& Johnson, E.A. (eds). Mixed cultures in biotechnology, McGraw-Hill, Inc., New York. pp. 39-68.

Ciani, M. \& Ferraro, L., 1998. Combined use of immobilized Candida stellata cells and Saccharomyces cerevisiae to improve the quality of wines. J. Appl. Microbiol. 85, 247-54

Fleet, G.H., Lafon-Lafourcade, S. \& Ribéreau-Gayon, P., 1984. Evolution of yeasts and lactic acid bacteria during fermentation and storage of Bordeaux wines. Appl. Environ. Microbiol. 48,1034-1038.

Gil, J.V., Mateo, J.J., Jimenez, M., Pastor, A. \& Huerta, T., 1996. Aroma compounds in wines as influenced by apiculate yeasts. J. Food Sci. 61, 1247-1249, 1266.

Granchi, L., Ganucci, D., Messini, A., Rosellini, D. \& Vicenzini, M., 1998 Dynamics of yeast populations during the early stages of natural fermentations for the production of Brunello di Montalcino wines. Food Technol. Biotechnol. 36, 313-318

Heard, G.M. \& Fleet, G.H., 1985. Growth of natural yeast flora during the fermentation of inoculated wines. Appl. Environ. Microbiol. 50, 727-728.
Heard, G.M. \& Fleet, G.H., 1986. Evaluation of selective media for enumeration of yeasts during wine fermentation. J. Appl. Bacteriol. 60,477-481.

Henschke, P.A. 1990. Evaluating wine yeasts for improved wine quality. In: Williams, P.J., Davidson, D.M. \& Lee, T.H. (eds). Proc. 7th Aust. Wine Ind. Tech. Conf., 13-17 August 1989, Adelaide, pp.157-165.

Hand, P., Ewart, A., Sitter, J., Maskides, A. \& Bruer, N., 2000. Techniques for chemical analysis and quality monitoring during winemaking. Patrick Hand Promotions, Cambelltown, Australia.

Jolly, N.P., Augustyn, O.P.H. \& Pretorius, I.S., 2003a. The occurrence of nonSaccharomyces yeast strains in four vineyards and grape musts in four production regions of the Western Cape, South Africa. S. Afr. J. Enol. Vitic. 24, 35^2.

Jolly, N.P., Augustyn, O.P.H. \& Pretorius, I.S., 2003b. The effect of nonSaccharomyces yeasts on fermentation and wine quality. S. Afr. J. Enol. Vitic. 24, $55-62$.

Longo, E., Cansado, J., Agrelo, D. \& Villa, T.G., 1991. Effect of climatic conditions on yeast diversity in grape musts from Northwest Spain. Am. J. Enol. Vitic. 42,141-144.

McCloskey, L., Arrhenius, S.P. \& Sylvan, M., 1995. New method to assess wine quality. Prac. Winery Vineyard 16, 30-33.

Miller, M.W. \& Phaff, H.J., 1998. Metschnikowia Kamienski. In: Kurtzman, C.P. \& Fell, J.W. (eds). The yeasts, a taxonomic study, Elsevier, Amsterdam, pp. 256 267 .

Nguyen, H-V. \& Panon, G., 1998. The yeast Metschnikowia pulcherrima has an inhibitory effect against various yeast species. Sci. Aliments. 18, 515-520.

Ott, R.L., 1998. An introduction to statistical methods and data analysis. Duxberry Press, Belmont, California.

Pretorius, I.S., Van der Westhuizen, T.J. \& Augustyn, O.P.H., 1999. Yeast biodiversity in vineyards and wineries and its importance to the South African wine industry - a review. S. Afr. J. Enol. Vitic. 20, 61-74.

Querol, A., Jimênez, M. \& Huerta., 1990. Microbiological and enological parameters during fermentation of musts from poor and normal grape harvests in the region of Alicante (Spain). J. Food Sci. 55,1603-1606.

Romano, P., Suzzi, G., Comi, G. \& Zironi, R., 1992. Higher alcohol and acetic acid production by apiculate wine yeasts. J. Appl. Bacteriol. 73, 126-130.

Romano, P., Suzzi, G., Comi, G., Zironi, R. \& Maifreni, M., 1997. Glycerol and other fermentation products of apiculate wine yeasts. J. Appl. Microbiol. 82, 625-618.

SAS, 1999. SAS/STAT user's guide, version 8, vol. 2 (1st printing). SAS Institute Inc., SAS Campus Drive, Cary, North Carolina 27513.

Schiitz, M. \& Gafner, J., 1993. Analysis of yeast diversity during spontaneous and induced alcoholic fermentations. J. Appl. Bact. 75, 551-558.

Shapiro, S.S. and Wilk, M.B., 1965. An analysis of variance test for normality (complete samples). Biometrika 52, 591-611.

Soden, A., Francis, I.L., Oakey, H. \& Henschke, P.A., 2000. Effects of cofermentation with Candida stellata and Saccharomyces cerevisiae on the aroma and composition of Chardonnay wine. Aust. J. Grape Wine Research 6, 21-30. 